\title{
Implementation Of Neuroscience Learning To Develop Early Childhood's Cognitive
}

\author{
Novfitri Kurniawati, Mustaji, Sri Setyowati \\ Universitas Negeri Surabaya \\ Surabaya, Indonesia \\ novfitri.kurniawati06@gmail.com
}

\begin{abstract}
This study aims to know in depth about the implementation of neuroscience learning to develop cognitively in Early childhood. Especially to stimulate brain structure so as to have a perfect executive function in the future. Due to the impact of globalization that changes the pattern of children to lazy move. So fewer children's gross motor stimulated that will affect the cognitive development and health in the future. It takes a gradual maturation of nerves that will prepare the child's. The research method used is a qualitative phenomenon of research subjects because it is rare for kindergartens to apply neuroscience learning. Neuroscience will be very effective if applied in early childhood brain development by using kinesthetic memory principles such as Alphabet Engram Kinesthetic is related closely related to the work function of the brain, that the movement of the body can provide nerve stimulation which can increase the memory capacity.
\end{abstract}

Keywords-Neuroscience Learning; cognitive development; early childhood

\section{INTRODUCTION}

Neuroscience can be interpreted as a science that specifically studies and assesses the nervous system or system of neurons (nerve cells) in humans. Basically, the discussion of neurosciences in learning cannot be separated from the brain structure and function of the brain.

Neurokinesthetic is a program that aims to restore the functions of motion to stimulate the maturity of nerves that can support the function of the brain structure. Through neuroscience activities, Dr. Anne Gracia [1] as an applied neuroscience practitioner and Togu Pardamean [2] as a kinesiology field stylist, felt the need to incorporate this program into motion activity. Because researchers believe "Motor to Cognitive" will have a true impact on children. Stages of activities in accordance with the above pyramid, the activity of motion serves to build a child sensor system.

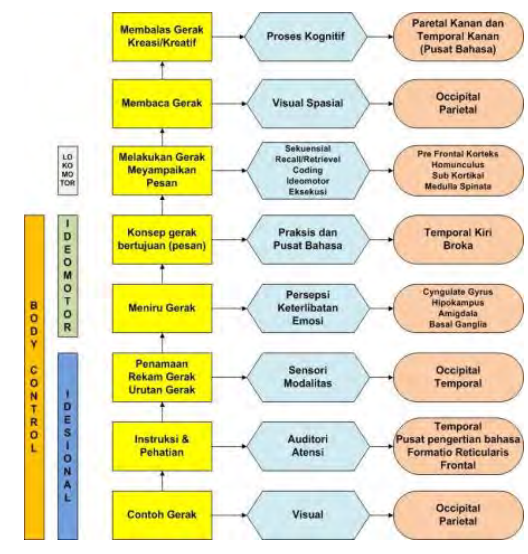

Fig.1 Motion search by Body Control [2]

The growing flow of information technology makes the lifestyle changes, not unlike the children's world. Many children today have been given gadgets or smartphones that provide plenty of fun apps and games, so kids will not get bored with the tool for hours. With such a lifestyle makes the child too lazy to move. A childhood that should be in the stimulus and play with his friends will eventually diminish and even neglected. The impact due to lack of stimulus in the muscles of children's muscles is seen after a few years later and it will also affect the physical health of children. Based on data WHO (World Health Organization) 2011 that most people move by just sitting in class or office for 8 hours a day. Globally 1 in 3 people will be vulnerable and potentially affected by chronic illness in the future. [3]

Early Childhood is at the Golden Age stage where at that time experiencing rapid growth, in the period for the optimal development of the necessary stimulations that can increase brain capacity. The child's physical motor ability should be kept in mind as it stimulates the rough muscle as well as the effect on the child's cognitive. The researchers found that there is a part of the brain that processes motion equally in part with the brain that processes learning. Children can learn in the best way when they are active because they stimulate neurons that facilitate the child's ability to get information and learning (Steven-Smith, 2016)

The Pyramid of Neural Maturity of William and Shellenberger's findings [4] shows that a child can not 
necessarily think comprehensively without going through certain stages related to the development of the age of Early Childhood. It takes a gradual maturity of nerves that will prepare the child's brain structure so as to have a perfect executive function.

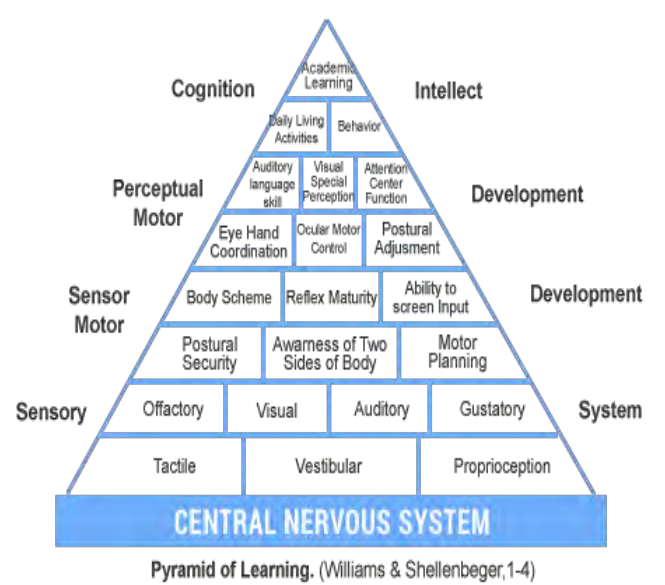

Fig. 2. Learning of pyramid William, Shellenberger [4]

It turns out that the sensory system is the first part that must be generated by stimulating to enter the second stage responsible for the development of sensory motor, the third stage where there is a perceptual development of the motor, and the fourth stage is cognitive/intellectual. If each stage is given the right stimulation, then a child's target has a highlevel thinking power to materialize. However, due to the instant desire of most adults, often the stages are missed, where stimulation is randomly assigned without proper understanding, resulting in many parts that should be prepared to support executive functions of the brain to be unprepared. In layman, this can be seen when a child is less able to think critically, less able to think strategically, less able to have empathy and much more. [5]

The technological advances in recent years have resulted in new methods that can show how the brain performs its functions while performing mental work involving learning and memory. The data generated from the application of these methods are highly relevant to teaching and learning that can have implications for learning, motivation, and development. Educators are increasingly interested in the findings of neuroscience research to improve teaching and learning [6]. The importance of early childhood brain development encompassing factors that influence development, developmental phases, critical periods in the development and development of language skills [7]. Recently developed kinesthetic memory method that is closely related to research that relates to the work function of the brain, that body movements can provide stimulation to the nerves that can increase memory capacity. [8]
One of the implementations of kinesthetic memory that can be applied in early childhood is the Kinesthetic Alphabet. The Kinesthetic Alphabet is a number of movements that make it easier for children to remember letters. This is very useful along with the introduction of early literacy, of course, movements that have been designed that can stimulate the nerves that can increase the memory capacity of the brain. Findings in the field of psychology there is a significant difference between children who enter PAUD institutions and those who do not follow it. According to Suyadi [9] there are three differences between children who enter the PAUD and those who do not, as follows: First, Hunt [10] states that the environment in the child's early years (0-6 years) will have a learning affect the long-term (long-term effect), children remember in a long period of time in this period until adulthood. Secondly, Bloom [11] analyzed earlier studies of published learning and the results suggest that about $70 \%$ of intellectual attitudes measured by IQ tests and about $50 \%$ of adult reading skills are established between age 4 and 9 years so it can be concluded that intellectual intelligence is not an inviolable "gift of God" but an endless process of development, and the development of IQ intelligence peaks at an early age. Third, Piaget [12] studies that the cognitive and intellectual processing systems of children are very different when compared with older children and even adults.

This research generally aims to describe the implementation of neuroscience learning in terms of planning, implementation, and assessment to develop children's cognitive, implementation constraints, influencing factors, who is involved and problem-solving efforts in the implementation of neuroscience learning.

\section{METHOD}

The design of this research is using a qualitative descriptive approach. The qualitative approach in this study is based on a phenomenological perspective. Type of approach that is done intensive, detailed, and comprehensive.

In this study the researchers conducted observations in kindergarten Al Uswah 2 Surabaya which has implemented learning neuroscience in learning from playgroup up to kindergarten . In this study is limited to 4-6 year age group and expected through this research can illustrates the implementation of the using neuroscience learning to develop cognitive ability in depth, so that obtained a clear and accurate picture.

The Sources of data in this study are 1). Head of Kindergarten I.2). Kindergarten teachers .3). Employees and 4) Kindergarten IT Al Uswah 2 Surabaya. In this study the research instrument using interview guides conducted with teachers, principals. It also uses observational guidance to children to know cognitive and motor development. As well as observation of the teacher to know the planning, implementation, evaluation conducted by teachers during the learning process. And Test data validity using the credibility 
test, transferability, dependability test, and compatibility test. In this study the credibility test uses triangulation.

Processing and analysis of data in this stage are done is analyzing the data that have been collected both the results of interviews, observations, and documentation associated with the study. The data that have been analyzed and reduced then displayed in a structured manner.

The presentation is defined as a set of arranged information that gives the possibility of conclusion and action taking. By presenting the data, the data can be organized, arranged in a relationship pattern, so it is easy to understand and plan the next work based on what is understood. [13]

\section{RESULTS AND DISCUSSION}

Based on the observation in kindergarten $\mathrm{Al}$ Uswah 2, the implementation planning of neuroscience learning is done at the beginning of activity called Morning Activity, that is at 7.30-09.00. There are several kinds of activities conducted, among others, motor physics class, journal class, study class, prayer class, and phonics class. Part of learning neuroscience is in the phonetic class.

The implementation of the phonetic class was divided into 2 groups namely the initial group and the follow-up group. This is done to facilitate in accommodating based on the ability of each child. Implementation of neuroscience learning in $\mathrm{Al}$ Uswah Kindergarten lies in the method taught. The method in this class of phonics has a special character because it is combined with the Kinesthetic Engram Alphabet. Alphabet Engram Kinesthetic is a kinesthetic engram stimulation activity for fitness and intelligence. Postural correction, balance, coordination, and movement of muscles will have an impact on learning fitness that is expected to correlate with the process of thinking and learning, thus impacting on improving academic quality.

Its application in the phonics class is that children imitate alphabetical movements to track postural correction. Balancing movements, coordination and muscle movement simultaneously will increase the concentration and stimulate the thinking ability of the child so that the child will increase learning achievement. Muscular maturity is very influential in the attention of attention, focus, and readiness to learn children.

For the method of reading the phonics program is also the implementation of neuroscience learning, because the steps are based on neuroscience theory. The cognitive process obtained through the phonic method is to combine visual sensory with the meaning that is in the head (Broca).

\section{Step 1. Sound the vowels}

The media used are Singing vowel song, vowel Poster, Alphabet Engram Kinesthetic.

The ability that is stimulated in this step is to know the letters and the shape of the letters, how to correct pronunciation using images, vowel posters, and games.
Postural letters A strikes A's equilibrium by lifting one-foot elbow and the elbow raised for a few seconds in turn. And other vowel letters with different movements.

Step 2 mentions the word sound

The tool used to mention the sound on the word with a limited 3 words can only use hand puppets, books, or pictures. And so on for the next stepstep.

For the assessment of learning outcomes, it is recorded in individual report books based on the stage of how many children have reached the development and what vocabulary can be achieved.

The neuroscience learning that was carried out in kindergarten Al Uswah 2 was in accordance with the stages of child development and proved to be very effective to use based on the assessment data for 2 years

For the Alphabet Engram Kinesthetic movement is as a basis for children's learning readiness through a good stimulus of balance, coordination, and maturity of muscles. Through the alphabetic movements, the child will understand the sequence, position, and control of motion according to William Schnellenberger's maturation theory (Mary Sue William, 1996) which makes the child's cognitive function complete through sensory, motor, perception and metabolism that will affect behavior (limbic).

While the phonetic method is applied also based on stages in accordance with the theory of neuroscience. The work process of Language, among others: sound origin, repetitive words, sound imitating letters, object identity, responsive language, expressive language, and grammar. The child's thinking flow will be formed according to Bloom's taxonomy, so the child's cognitive will increase.

Literacy skills that are stimulated through referrals, recognizing letters, spelling, writing, visual reading, listening and social interaction will provide meaningful learning for the child and will be stored in Long-term memory

\section{References}

[1] A. Gracia, Handbook of Spiral Development Maturity, Jakarta: Smart Brain Energy, 2014.

[2] T. P. Sinaga, Rangkaian Gerak Alphabet Engram Konestetik Neurokinestetik sebagai Pedoman Menyusun Aktivitas Gerak, Jakarta: Smart Brain Energy, 2015.

[3] W. H. Organization, "New Physical Activity guidance can help reduce risk of breast, colon cancers," World Health Organization, 2011.

[4] S. S. Mary Sue William, An Introduction to: How Does Your Engine Run, Therapy Works, 1996.

[5] Budiwardani, "Membangun Kecerdasan Melalui Kinestetik," 1 Januari 2014.

[6] B. \&. Fox, "The Educational Relevance of Research in Cognitive Neuroscience," Educational Psychology Review, pp. 297-342, 1998. 
[7] D. H. Schunk, Learning Theories, Jakarta: Pustaka Pelajar, 2012.

[8] B. E. Fiecher, Action Effects in Perception and action, The Ideo Approach, Frontier, 2007.

[9] Suyadi, Teori Pembelajaran Anak Usia Dini dalam Kajian Neurosains, Bandung: Remaja Rosdakarya, 2014, p. 8

[10] A. Sudjud, Pendidikan Pra Sekolah, Yogyakarta: UNY Press, 1978.

[11] B. Bloom, Taxonomy of Educational Objectives. Handbook1: Cognitive Domain, New York: Mc Key, 1956.

[12] J. Piaget, The Psychology of Intelligence, London: Routledge and Kegan Paul, 1950

[13] M. M. a. Huberman, Analisis Data Kualitatif: Buku Sumber Tentang Metode-Metode Baru, Jakarta: UI Press, 2014.

[14] D. A. Steven-Smith, "Active Bodies/Active Brains: The Relationship Between Physical Engagement and Children's Brain Development," The Physical Educator, pp. 719-732, 2016.

[15] B. Bloom, Taxonomy of Educational Objectives: The Clasification of Educational goals. Handbook : Cognitive Domain, New York: McKay, 1956

[16] T. Pasiak, Tuhan Dalam Otak Manusia, Mewujudkan Kesehatan Spriritual Berdasarkan Neurosains, Bandung: Mizan, 2012.

[17] Wikipedia, "Neurosains," 13 November 2012. [Online]. Available: http:/id.wikipedia.org/wiki/neurosains.

[18] T. Pasiak, "Pendidikan Karakter sebagai Pendidikan Otak," in Mengatasi Masalah Narkoba dengan Welas Asih, Jakarta, Gramedia, 2012, pp. 190-192.

[19] Suyadi, "Model Pendidikan Karakter dalam Konteks Neurosains," in Seminar Nasional Fakultas Tarbiyah UIN Sunan Kalijaga, Yogyakarta, 2012.

[20] G. S. Morrison, Dasar-Dasar Pendidikan Anak Usia Dini (PAUD), Jakarta: Indeks, 2012.

[21] P. Supomo, Teori Perkembangan Kognitif Jean Piaget., Jakarta: Kanisius, 2012

[22] A. W. Gunawan, Genius Learning, Jakarta: Gramedia, 2003.

[23] S. d. M. Pudjiati, Mengasah Kecerdasan di usia 0-2 Tahun, Jakarta: Dirjen PAUDNI, 2011.

[24] S. Maslihah, "Deteksi Dini Perkembangan Kognitif Anak," Penyuluhan Deteksi Dini Tumbuh Kembang Anak dalam Upaya Optimalisasi Perkembangan Anak Usia Dini di Kecamatan Cisarua, 18 Agustus 2005

[25] H. Alwi, Kamus Besar Bahasa Indonesia, Jakarta: Balai Pustaka, 2002.

[26] L. E. Berk, Child Development Seventh Edition, Boston: Pearson and Edition, 2006

[27] S. Y. LN, Psikologi Perkembangan Anak dan Remaja, Bandung: Remaja Rosdakarya, 2012

[28] S. Yusuf, Psikologi Perkembangan Anak dan Remaja, Bandung: Remaja Rosdakarya, 2012

[29] S. Patmodewo, Pendidikan Anak Pra Sekolah, Jakarta: Rineka Cipta, 2003
[30] B. Sujiono, Metode Perkembangan Fisik, Jakarta: Universitas Terbuka, 2009

[31] S. B. Energy, "Motor to Cognitive Sosialisasi Alfabet Engram Kinestetik," Buletin Kegiatan Sosial, 26 Maret 2013.

[32] M. Jamaris, Perkembangan dan Pengembangan Anak Usia Taman Kanak-Kanak, Pedoman bagi Orang Tua dan Guru, Jakarta: Grasindo, 2006.

[33] Hainstock, Montessori untuk Anak Prasekolah, Jakarta: Pustaka Dela Prasta, 2002

[34] F. M. d. N. Rahmawati, Permaianan Edukatif Pendukung Pembelajaran Bahasa Arab, Yogyakarta: UI Press, 2012.

[35] A. Adityasari, Main Matematika Yuk, Jakarta: Gramedia, 2013.

[36] J. R. d. S. Kandou, Pembelajaran Matematika Dasar Bagi Anak Berkesulitan Belajar, Yogyakarta: Ar-Ruz Media, 2014.

[37] Kementrian Pendidikan dan Kebudayaan, Pedoman Pengenalan Kurikulum PAUD, Jakarta: Direktorat Pembinaan Anak Usia Dini, 2015

[38] T. Pasiak, Manajemen Kecerdasan Memberdayakan IQ, EQ dan SQ untuk Kesuksesan Hidup, Bandung: Mizan Pustaka, 2006.

[39] D. H. Schunk, Learning Theories An Educational Perspektif, Bandung: Remaja Rosdakarya, 2012.

[40] B. Sujiono, Metode Pengembangan Fisik, Jakarta: Universitas Terbuka, 2010

[41] B. a. Copple, Develompmentally Appropriate Practice in Early Childhood Programs : Revised, Washington DC: National Assosiation for The Eduvation of Young Childern, 1997.

[42] Suyanto, Konsep Dasar Anak Usia Dini, Jakarta: Kencana Media Group, 2005

[43] Y. N. d. Sujiono, Konsep Dasar Pendidikan Anak Usia Dini, Jakarta: Indeks, 2009.

[44] E. Jensen, Brain Based Learning, The New Science of Teaching \& Training, Revised Edition, California: Sage Corwin Press, 2007.

[45] W. S. Kuswana, Taksonomi Kognitif, Perkembangan Ragam Berpikir, Bandung: Remaja Rosda karya, 2014.

[46] D. d. Mudjiono, Belajar dan Pembelajaran, Jakarta: Rineka Cipta, 2010

[47] S. Munaf, Evaluasi Pendidikan Fisika, Bandung: Universitas Pendidikan Indonesia, 2001

[48] L. d. K. Anderson, A Taxonomy for Learning, Teaching and Assesing : A Revision of Bloom's Taxonomy of Educational Objectives, New York: Longman, 2001.

[49] S. A. Bunda, Balita dan Masalah Perkembangannya, Jakarta: Gaya Favorit Press, 2001.

[50] P. Strick, Introducing: The Psychologist, 1995.

[51] G. Doman, Teach Your Baby to Read: The Gentle Revolution, London: J.Cape Publication, 1994.

[52] W. C. a. G. Ojemann, Conversation's with Neil's Brain, Reading, New York: Addison-Wesley Publishing Co., 1994. 
[53] J. Rihlah, "Pembelajaran Sentra Balok dalam Menstimulasi Perkembangan Kognitif dan Sosial Emosional Anak Kelompok A di TK Khadijah Pandegiling Surabaya," Tesis, UNESA, 2016.

[54] F. A. D. S. Rindu Dwi M.S, "Kaitan Antara Status Gizi, Perkembangan Kognitif, Dan Perkembangan Motorik Pada Anak Usia Prasekolah," Penelitian Gizi dan Makanan Vol.36 IPB, pp. 62$72,2013$.

[55] I. Amanah, "Pengaruh Outdoor Learning terhadap Perkembangan Kognitif dan Perkembangan Fisik Motorik Anak Kelompok B di Kecamatan Krian Kabupaten Sidoarjo," Tesis, UNESA, 2014.

[56] B. M. D. M. c. P. PhilipD. Tomporowski, "Exercose and Children's Cognition : The Role of Exercise Charateristics ang Place for Metacognition," Journal of Sport and Health Science, pp. 47-55, 2015 .

[57] A. M. Lisle, "Cognitive Neuroscience in Education: Mapping NeuroCognitive Processes and Structures to Learning Styles, can it be done?," The British Educational Research, 2006.

[58] S. Deborah A. Stevens, "Active Bodies/Active Brains: The Relationship Between Physical Engagement and Children's Brain Development," The Physical Educator, pp. 719-732, 2016.

[59] Depdiknas, Kerangka Dasar Kurikulum PAUD, Standar dan Bahan Ajar PAUD Formal, Jakarta: Depdiknas, 2007.

[60] Depdiknas, Kerangka dasar dan Struktur Kurikulum 2013 Pendididkan Anak Usia Dini, Jakarta: Kementrian Pendidikan dan Kebudayaan, 2015.

[61] L. Moleong, Metodologi Penelitian Kualitatif, Bandung: Remaja Rosdakarya, 2002.

[62] N. S. Sukmadinata, Metode Penelitian Pendidikan, Bandung: Remaja Rosdakarya, 2012

[63] J. W. Creswell, Research Design Pendekatan Kualitatif, Yogyakarta: Pustaka Pelajar, 2014.

[64] S. Faisal, Penelitian Kualitatif: Dasar-Dasar dan Aplikatif, Malang: YA3, 1990.
[65] Koentjaraningrat, Metode Penelitian Masyarakat, Jakarta: Gramedia, 1991.

[66] B. d. S. Biklen, Qualitative Research for Education: An Introduction to theory and methods, Boston: Allyn \& Bacon, 1992.

[67] L. J. Moleong, Metode Penelitian Kualitatif Edisi Revisi, Bandung: Remaja Rosdakarya, 2011.

[68] S. Arikunto, Prosedur Penelitian: Suatu Pendekatan Praktik, Jakarta: Rineka Cipta, 2010.

[69] Kartini-Kartono, Pemimpin dan Kepemimpinan, Jakarta: Raja Grafindo Persada, 2008

[70] M. Idrus, Metode Penelitian Ilmu Sosial, Pendekatan Kualitatif dan Kuantitatif, Jakarta: Erlangga, 2009.

[71] B. Bungin, Penelitian Kualitatif Komunikasi, Ekonomi, Kebijakan Publik dan Ilmu Sosial, Jakarta: Putra Grafika, 2007.

[72] S. W. R. D. F. R. K. Diane E Papalia, A Child's World : Infancy Through Adolensence, Mishawaka: Macgraw Hill, 2004.

[73] T. Ikrar, Ilmu Neurosains Modern, Jakarta: Pustaka Pelajar, 2016

[74] I. Henanta, Ilmu Kedokteran Lengkap Tentang Neurosains, Yogyakarta: D-Medika, 2013.

[75] H. Gardner, Multiple Intelligence, Jakarta: Indek, 2007.

[76] R. A. Wilson, The MIT Encyclopedia of the Cognitive Science, MIT Press, 1993

[77] H. Usman, Metodologi Penelitian, Jakarta: Bumi Aksara, 2009.

[78] Y. L. a. N. K. Denzin, Handbook of Qualitative Research, Yogyakarta: Pustaka Pelajar, 2009. 